\title{
MODELLING OF GROWTH FACTORS OF COFFEE PROCESSING COMPANIES
}

Daniela Nuševa ${ }^{1}$, Stojanka Dakić ${ }^{2}$ Dejan Jakšićc ${ }^{3}$, Kristina Mijić4 ${ }^{4}$ Dušan Saković ${ }^{5}$

*Corresponding author E-mail: kristina.mijic@ef.uns.ac.r约

A R T I C L E I N F O

Review Article

Received: 14 January 2021

Accepted: 25 May 2021

doi:10.5937/ekoPolj2102435N

UDC 330.341:[658.15:633.73

Keywords:

growth, financial statement, coffee market, panel analysis

JEL: M41, D40, C19

\section{A B S T R A C T}

In this paper, the growth factors of coffee processing companies in the Republic of Serbia were analyzed by panel data technique. The growth was measured by changes in sales, while as explanatory variables were defined the following: export, size, capital turnover, revenue cycle, current ratio (liquidity ratio), debt ratio and return on assets. The empirical examination was conducted on the basis of 160 observations of financial statements of companies in coffee market. The results show that coffee processing companies in the Republic of Serbia have an average positive growth rate (1.08) during period 20152018. Growth of coffee processing companies is significant negatively related to size, revenue cycle and current ratio. On the other side, profitability measured as return on assets has positive significant impact on firm growth. The results show the performances of coffee processing companies during period 2015-2018 and the profile of growth factors as a prerequisite for company's development. This information can be useful for the large number of internal and external users of financial statements in the process of decision making.

(C) 2021 EA. All rights reserved.

1 Daniela Nuševa, Ph.D., Assistant Professor, University of Novi Sad, Faculty of Economics in Subotica, Segedinski put 9-11, 24000 Subotica, Republic of Serbia, Phone: +381 24628 000, E-mail: daniela.nuseva@ef.uns.ac.rs, ORCID ID (https://orcid.org/0000-0002-0990-428X)

2 Stojanka Dakić, Ph.D., Assistant Professor, University of Novi Sad, Faculty of Economics in Subotica, Segedinski put 9-11, 24000 Subotica, Republic of Serbia, Phone: +381 24628 000, E-mail: stojanka.dakic@ef.uns.ac.rs, ORCID ID (https://orcid.org/0000-0002-2416-7847)

3 Dejan Jakšić, Ph.D., Full Professor, University of Novi Sad, Faculty of Economics in Subotica, Segedinski put 9-11, 24000 Subotica, Republic of Serbia, Phone: +381 24628 000, E-mail: dejan.jaksic@ef.uns.ac.rs, ORCID ID (https://orcid.org/0000-0003-1711-1869)

4 Kristina Mijić, Ph.D., Assistant Professor, University of Novi Sad, Faculty of Economics in Subotica, Segedinski put 9-11, 24000 Subotica, Republic of Serbia, Phone: +381 24628 000, E-mail: kristina.mijic@ef.uns.ac.rs, ORCID ID (https://orcid.org/0000-0001-9851-1025)

5 Dušan Saković, Ph.D., Assistant Professor, University of Novi Sad, Faculty of Economics in Subotica, Segedinski put 9-11, 24000 Subotica, Republic of Serbia, Phone: +381 24628 000, E-mail: dusan.sakovic@ef.uns.ac.rs, ORCID ID (https://orcid.org/0000-0003-2742-2388) 


\section{Introduction}

Coffee is one of the world's most traded commodities. It provides economic benefits for all the internationally dispersed participants of the global value chain, from growers to consumers. Coffee commercialization contribute to growth of total household incomes in the producing countries (Sharma et al., 2016). It also, contribute to growth of foreign exchange revenues, tax collection and GDP for more than 140 exporting countries of whole grain coffee and over 100 exporting countries of coffee (Silva, Leite, 2013). On the other side, it brings out huge profits for the processors and retailers mainly located in the importing countries. To achieve sustainable development of coffee sector, private and public targeted investments are required to boost the produced quantities and improve the quality premiums in international markets (Al-Abdulkader et al., 2018).

Coffee production is concentrated in many tropical and subtropical countries, mostly in the developing world. The total world production of whole grain coffee or green coffee beans amounted 170.9 million $60 \mathrm{~kg}$ bags in 2018/19 (International Coffee Organization, 2020a). The leading coffee producing countries were Brazil (62.9 million $60 \mathrm{~kg}$ bags or $36.8 \%$ ), Vietnam (31.2 million $60 \mathrm{~kg}$ bags or $18.3 \%$ ), Columbia (13.9 million $60 \mathrm{~kg}$ bags or $8.1 \%$ ), and Indonesia (9.4 million $60 \mathrm{~kg}$ bags or $5.5 \%$ ).

Most of the produced volume is exporting, providing substantial export earnings for the developing and least developed countries. The value exported in 2018 was estimated at US\$30.6 billion (International Trade Centre, 2020). The largest share in value in the world`s coffee export in 2018 had Brazil (14.3\%), Vietnam (9.4\%) and Germany (8.3\%).

The global demand for coffee continues to grow. World coffee consumption reached 169.3 million $60 \mathrm{~kg}$ bags in 2019/20 (International Coffee Organization, 2020b). The major coffee consuming markets are still in the most developed countries, such as EU, with the market share of approximately $27 \%$, and US with the market share of approximately $16.5 \%$ of the total world coffee market. It is important to point out that there is a growing domestic consumption in the exporting countries $(1.7 \%$ CAGR from $2016 / 17$ to $2019 / 20$ ) and in the non-traditional coffee markets as well. Brazil, as the world leading coffee producing and exporting country, with the consumption of 22.3 million $60 \mathrm{~kg}$ bags or 13\% in 2019/20 represented a third world's consuming market.

The Serbian coffee market is expected to generate revenue of US\$469 million in 2020 (Average Revenue per Capita of US\$67.44), and growth by $4.3 \%$ annually (CAGR 2020-2025) (Statista, 2020). It is small and highly concentrated market. There is a gap between the two dominant manufacturers, Grand Prom and Strauss Adriatic, on the one side, and around 300 small domestic roasters on the other side. The main focus for all of them is the segment of traditional roast and ground coffee, which makes almost $90 \%$ of the total Serbian coffee market. The combined share of the largest two players accounts approximately $3 / 4$ of the traditional roast and ground coffee market. The two major competitors in the Serbian coffee industry gained about $73 \%$ of total revenue during 2012-2015 (Nuševa et al., 2017). Primary focus of the few multinational companies which are present on the market is the segment of instant coffee. 
The aim of paper is to investigate the factors that have impact on growth of coffee processing companies in Serbia. Growth as an increase in sales represents one of the precondition for business success and development. Financial statements represent the base for analysis business performances (see more: Hasanaj, 2019; Callado, Soares, 2014; Milić, Mijić, Jakšić, 2018). The analysis is based on 160 observations of financial statements of coffee processing companies during period 2015-2018. Financial statements provide information about position and business success. Based on panel data analysis the research analysis has to define which factors have significant impact on growth of coffee processing companies.

\section{An overview of the Serbian coffee market}

Coffee plays a special role in Serbia's foreign trade. The country does not produce coffee, but imports, processes and exports it. Coffee import in Serbia was estimated at US\$73,296 thousand or 31,580 tons in 2019 (International Trade Centre, 2020). The biggest share due to its value in Serbia's import in 2019 had Brazil (14.5\%), Italy (10.1\%), Vietnam (6.7\%), Uganda (4.7\%), Switzerland (2.2\%) and Greece (1.6\%). As Serbia has small share of approximately $0.2-0.3 \%$ of the total world imports of coffee, it does not represent as significant market as some other countries.

Exported value of coffee by Serbia in 2019 accounted US\$7,717 thousand or 1,255 tons (International Trade Centre, 2020). The major exporting markets due to its value in 2019 were Austria (19.2\%), Montenegro (16.8\%), North Macedonia (10.7\%), Germany $(8.1 \%)$, Bosnia and Herzegovina (7.4\%) and Netherlands (5.5\%).

Coffee is very popular beverage among Serbian consumers and the country is among the top countries in coffee consumption per capita. Coffee consumption is estimated around 35,000 tons per year. One of the biggest problems is the fact that around 15 to $20 \%$ of that is illicit, illegal or smuggled coffee. To address these issues, new legislation was introduced on 1 January 2018 (Ministry of finance of Republic of Serbia, 2017). All coffee products with more than $50 \mathrm{~g}$ net weight are obligated to have a banderole and processors need to pay excise taxes for them.

Of a great concern is the fact that there are no detailed declarations on the packaging showing the country of origin, health and sanitary safety standards, percentage of each coffee bean, etc. Coffees in Serbia are generally blends of Arabica and Robusta beans, with larger presence of Robusta. The highest quality and also priciest coffees and blends are pure Arabica. So, consumers in Serbia can be misled by the price or quality, or there may be a risk for their health. Constant education of consumers is very important for their safety.

Serbian consumers prefer roasted and groud (traditional, domestic, black, fresh, Turkish or Serbian) coffee, particularly the older generations. The younger generations are more in favour of instant coffees (including different mixtures), and that is one of the main reason that instant coffee segment rises. Revenue in the instant coffee segment amounts to US\$386 million in 2020 (Statista, 2020). In the previous years, leaders in the 
instant coffee segment in Serbia, Nestle Adriatic (part of Nestle) and Mondelez EAM (former Kraft Foods, part of Mondelez International), are facing strong competition from Grand Prom and Strauss Adriatic. The two domestic manufacturers are constantly monitoring the habits and attitudes of the consumers and implementing innovations such as development of new coffee brands, "mixes" and ways of consuming, coffee shops, coffee-to-go etc.

As consumer awareness about the sustainable development in coffee sector increases, niches of coffees carrying certification labels (Organic, Fairtrade, UTZ Certified, Rainforest Alliance, etc.) are experiencing growth, primarily in the developed countries (Nuševa, 2018). Due to many factors, such as: weak purchasing power, low consumer recognition, lack of awareness and education campaigns, insufficient adherence to quality standards and systems, etc., there is no significant demand for these coffees in Serbia yet.

\section{Literature review}

The aim of the business of the company is long-term business in the market and profit. In the conditions of market competition, frequent economic changes, the growth of the company is set as a prerequisite for the survival and development of the company in the market. Growth is one of the goals of company. Besides that, growth is one of the prerequisites for the achievement of other business goals such as increasing market share, reducing the business risk in market etc. The positive side of company growth is reflected not only on the particular company, but also on the industry and overall economy. Company growth lead to employment increase, economic growth etc. (see more: Poljašević, Mijić, 2017).

Information on the position and success of the company is presented in the financial statements. Financial statement analysis methods are used to obtain information about different performances of company (see more: Subačienè et al. 2018; Jakšić, Mijić, Zekić, Poljašević, 2015). Such information points to profitability, growth, leverage, debt, liquidity etc. Information is relevant to the various stakeholders in order to provide an adequate decision making (see more: Gulin, Grbavac, Hladika, 2016).

There are different definitions of company growth, as well as different variables that indicate growth. The growth of firm can be represented by the change of some variable over time (Machek, Machek, 2014). Growth can be defined in terms of revenue generation, value addition, and expansion in terms of volume of the business. It can also be measured in the form of qualitative features like marketposition, quality of product, and goodwill ofthe customers (Gupta, Guha, Krishnaswami, 2013). According to Gopinath (2012) firm growth is an increase in certain attributes such as sales, employment or profit between two points in time and is an important determinant of firms performance. The two most common variables that indicate growth are the change in sales and employment (Delmar, 2006; Daunfeldt, Elert, Johansson, 2014.). Shepherd and Wiklund (2009) determined the changes in sales as the most relevant and reliable variable of firm growth. 
The firm growth can be result of organic or non-organic growth (Machek, Machek, 2014). Organic growth is the result of investments in an existing business, such as investments in the development of new products or services (Harabi, 2003). If the growth of a company is due to the merger or acquisition then it is a non-organic growth of the enterprise. Usually the growth through merger or acquisition processes leads to a significant increase in market concentration.

Investigations of the factors that influence firm growth has been the subject of examination by numerous authors. The impact of leverage ratio and variable whether the company had a loan request rejected by a bank or not on the growth of company was examined by Becchetti and Trovato (2002). They found out that leverage ratio does not have significant impact on growth, while the dummy variable has the significant impact on growth.

The factors that affect sales growth in Greek manufacturing small and medium sized enterprises were examined by using a panel data analysis. The results indicate that profitability, liquidity, reliance on long-term debt, employee productivity, fixed assets turnover and restricted sales credit terms have significant influence on firm growth (Voulgaris, Asteriou, Agiomirgianakis, 2003).

Hermelo and Vassolo (2007) conducted the research of determinants of firms's growth among the companies in Argentina. The results of regression analysis show that investment in newer technology, export and return on sale have significant impact on growth. On the other side, they found out that size of company does not have significant impact on firm growth.

The factors that affect growth of real estate investment trusts in US were investigated by using a panel data model of 148 REITs during the period 1993-2005. The results show that size, age and leverage are related to growth. The results show that young REITs have a better growth rate (Gopinath, 2012).

Fiala and Hedija (2015) used an ordinary least squares estimator to investigate the relationship between firm size and firm growth in the Czech Republic during 20072012. Size of company was measured by revenue, number of employees and total assets. The results show that there is a negative significant relationship between firm size and firm growth. Furthermore, the results are not influenced of the type of firm size indicator, because for all three used indicators are results very similar.

\section{Materials and methods}

The subject of the research in this paper is to determine how selected internal factors (export, size, capital turnover, revenue cycle, current ratio, debt ratio and return on assets) influence on growth rate of selected coffee processing companies in Serbia. According to the subject, the aim of this paper is to analyze growth of coffee processing companies in Serbia in context of internal factors which are outlined. 
The study covers period from 2015 to 2018 (4 years) and includes 40 coffee processing companies. Total number of observation is 160 . The data were collected from the Scoring database (Scoring, 2019). The sample is consist of financial statements of coffee processing companies in Serbia. Financial statements provide information about financial position and results of companies in the thousand of RSD.

In accordance with the subject and the aim of the research, the following hypothesis was set up:

$H_{1}$ : Internal factors, such as export, size of company, capital turnover, revenue cycle, current ratio (liquidity ratio), debt ratio and return on assets have a significant impact on firm growth of selected coffee processing companies in Serbia.

The research is based on a panel regression analysis. Panel analysis is well suited for comparative data analysis because it allows researchers great flexibility in modeling the differences in the behavior of different subjects. The panel data analysis provide a solution for the data which are not sufficient for time series analysis and spatial analysis, because their pooling enable the data which give better research results (Aljinovic, Marasovic, 2012). Balanced panel data were used in the paper, since we have the same number of time series observations for each comparative unit.

There are a number of different models for panel data, however, in the broadest sense we can split into: a) 'Pooled OLS' model b)Fixed effect model and c) Random effect model. The Pooled OLS model is the simplest panel model, and is defined as:

$$
Y_{i t}=\alpha+\beta_{1} \cdot x_{i t 1}+\beta_{2} \cdot x_{i t 2}+\cdots+\beta_{K} \cdot x_{i t K}+\varepsilon_{i t} ; i=1,2, \ldots, N ; t=1,2, \ldots, T
$$

where $N$ represents the number of observation units, T represents the number of time periods, $x_{i t K}, k=1,2, \ldots, K$ is the value of $k$ of the independent variable, and of the observation unit at time $t$. The parameter $\alpha$ represents a constant that is the same for all observation units and does not change over time. $\beta_{1}, \beta_{2}, \ldots, \beta_{K}$ are the parameters to be estimated. $\varepsilon_{i t}$ is the error of the relation of the $i$ observation unit in period $t$ and it is assumed that $\varepsilon_{i t} \varepsilon_{i t}$ is independently and identically distributed random variables across units of observation and in time. With all this, the assumption is that all $x_{i t K}$ are independent with $\varepsilon_{i t}$ for all $i, t, k$.

The Pooled OLS model has the most limitations, so the mostly used regression models in panel analysis are the model of fixed effects or the model of random effects.

Growth as a dependent variable is measured as change in sales during two period. On the other side, on the basis of available data, the explanatory variables are defined as export, size, capital turnover, revenue cycle, current ratio (liquidity ratio), debt ratio and return on assets. Growth, export, capital turnover, current ratio, debt ratio and return on assets are represents as ratio. Size is represented as natural logarithm of total assets, while revenue cycle is represent as logarithm of the average number of days a claim is collected. List of variables used in panel models is given in Table 1. 
Table 1. List of variables used in panel analysis

\begin{tabular}{|c|c|c|c|c|}
\hline Variable name & $\begin{array}{l}\text { Variable } \\
\text { code }\end{array}$ & $\begin{array}{c}\text { Type of } \\
\text { variable }\end{array}$ & Definition & Explanation \\
\hline Growth & Growth & Dependent & $\begin{array}{c}\text { Firm growth during } \\
2015-2018\end{array}$ & Sales $_{t} /$ Sales $_{t-1}$ \\
\hline Export & Export & Explanatory & $\begin{array}{c}\text { Export share in total } \\
\text { sales revenues }\end{array}$ & $\begin{array}{c}\text { Export share revenue / } \\
\text { Sales } \\
\end{array}$ \\
\hline Size & Size & Explanatory & Size of company & Ln Total Assets \\
\hline Capital turnover & CapTurn & Explanatory & $\begin{array}{l}\text { Measures capital } \\
\text { intensity of firm }\end{array}$ & $\begin{array}{l}\text { Measures capital } \\
\text { intensity of firm }\end{array}$ \\
\hline Revenue cycle & RevCyc & Explanatory & $\begin{array}{l}\text { Days in accounts } \\
\text { receivable }\end{array}$ & $\begin{array}{c}\text { Log The average number } \\
\text { of days a claim is } \\
\text { collected }\end{array}$ \\
\hline Current ratio & CurrRatio & Explanatory & $\begin{array}{c}\text { Company's ability to pay } \\
\text { off its current liabilities }\end{array}$ & $\begin{array}{c}\text { Current assets / Current } \\
\text { liabilities } \\
\end{array}$ \\
\hline Debt ratio & Debt & Explanatory & Company's leverage & Total debt / Total assets \\
\hline Return on assets & ROA & Explanatory & Company's profitability & Net income / Total assets \\
\hline
\end{tabular}

Source: Authors' illustration based on Walsh, 2003; Hasanaj, 2019.

\section{Results}

In Table 2 is presented the descriptive statistics of the variables used in panel analysis. According to the results of descriptive statistics it can be concluded that coffee processing companies in the Republic of Serbia have an average positive growth during 2015-2018. Based on mean value the average rate is $8 \%$, while based on median value the average growth rate is $5 \%$. The examination of current ratio shows the wide range of liquidity of coffee processing companies. Current ratio according to the median value shows that coffee processing companies in the Republic of Serbia have problems in paying current liabilities on time. The results of debt ratio analysis show that in average coffee processing companies have more liabilities than capital. The positive average value of return on assets indicate that coffee processing companies in Serbia make a net income of $7 \%$ of total assets.

Table 2. Descriptive statistics for period 2015, 2018 and period from 2015-2018

\begin{tabular}{|c|r|r|r|r|r|r|r|r|}
\hline \multirow{2}{*}{$\begin{array}{c}\text { Variable } \\
\text { name }\end{array}$} & \multicolumn{1}{c|}{$\mathbf{2 0 1 5}$} & \multicolumn{1}{|c|}{$\mathbf{2 0 1 8}$} & \multicolumn{6}{|c|}{ Period 2015 - 2018 } \\
\cline { 2 - 9 } & Mean & Mean & Mean & Median & Minimum & Maximum & Std. Dev. & $\begin{array}{c}\text { No. } \\
\text { obs. }\end{array}$ \\
\hline Growth & 1.14 & 1.05 & 1.08 & 1.05 & 0.50 & 2.91 & 0.24 & 160 \\
\hline Export & 0.05 & 0.06 & 0.06 & 0.00 & 0.00 & 0.99 & 0.17 & 160 \\
\hline Size & 10.57 & 10.99 & 10.83 & 10.83 & 5.79 & 16.01 & 1.88 & 160 \\
\hline $\begin{array}{c}\text { Capital } \\
\text { turnover }\end{array}$ & 2.19 & 1.87 & 2.07 & 1.48 & 0.21 & 12.13 & 1.86 & 160 \\
\hline $\begin{array}{c}\text { Revenue } \\
\text { cycle }\end{array}$ & 1.59 & 1.59 & 1.59 & 1.67 & -0.04 & 2.63 & 0.58 & 160 \\
\hline
\end{tabular}




\begin{tabular}{|c|r|r|r|r|r|r|r|r|}
\hline \multirow{2}{*}{$\begin{array}{c}\text { Variable } \\
\text { name }\end{array}$} & \multicolumn{1}{|c|}{$\mathbf{2 0 1 5}$} & \multicolumn{1}{|c|}{$\mathbf{2 0 1 8}$} & \multicolumn{6}{|c|}{ Period 2015 - 2018 } \\
\cline { 2 - 9 } & Mean & Mean & Mean & Median & Minimum & Maximum & Std. Dev. & $\begin{array}{c}\text { No. } \\
\text { obs. }\end{array}$ \\
\hline $\begin{array}{c}\text { Current } \\
\text { ratio }\end{array}$ & 2.15 & 2.27 & 2.29 & 1.51 & 0.27 & 12.96 & 2.08 & 160 \\
\hline Debt ratio & 0.67 & 0.57 & 0.59 & 0.62 & 0.02 & 2.73 & 0.42 & 160 \\
\hline $\begin{array}{c}\text { Return on } \\
\text { assets }\end{array}$ & 0.05 & 0.08 & 0.07 & 0.05 & -0.55 & 0.45 & 0.11 & 160 \\
\hline
\end{tabular}

Source: Author's calculation

Independent variables correlation was done to determine if there was a multicollinearity problem. A high correlation between individual variables may indicate the presence of multicollinearity. Multicollinearity can be a problem if the correlation between variables exceeds 0.80 (Field, 2005).

Table 3. Pearson correlation coefficient

\begin{tabular}{|r|r|r|r|r|r|r|r|c|}
\hline Growth & Export & Size & \multicolumn{1}{l}{$\begin{array}{l}\text { Capital } \\
\text { turnover }\end{array}$} & $\begin{array}{l}\text { Revenue } \\
\text { cycle }\end{array}$ & $\begin{array}{l}\text { Current } \\
\text { ratio }\end{array}$ & Debt ratio & $\begin{array}{l}\text { Return } \\
\text { on assets }\end{array}$ & \\
\hline 1 & -0.041 & -0.055 & 0.254 & -0.203 & -0.167 & 0.088 & 0.248 & Growth \\
\hline & 1 & 0.343 & -0.249 & 0.210 & 0.056 & -0.161 & -0.050 & Export \\
\hline & & 1 & -0.236 & 0.102 & 0.128 & -0.442 & 0.072 & Size \\
\hline & & & 1 & -0.555 & 0.005 & 0.118 & 0.173 & $\begin{array}{c}\text { Capital } \\
\text { turnover }\end{array}$ \\
\hline & & & & 1 & 0.205 & -0.212 & -0.139 & Revenue cycle \\
\hline & & & & & 1 & -0.506 & 0.101 & Current ratio \\
\hline & & & & & & & -0.142 & Debt ratio \\
\hline & & & & & & & & $\begin{array}{c}\text { Return on } \\
\text { assets }\end{array}$ \\
\hline
\end{tabular}

Source: Authors

As we can see in Table 3 none of the correlations are even close to the threshold value of 0.8 , so we can conclude that there is no problem with multicollinearity.

The Table 4 shows all three models.

Table 4. Panel models

\begin{tabular}{|c|c|c|c|}
\hline \multirow{2}{*}{ Explanatory variables } & \multicolumn{3}{|c|}{ Coefficient } \\
\cline { 2 - 4 } & Model 1 & Model 2 & Model 3 \\
\hline \multirow{2}{*}{ Const } & 1,0692 & 4,7420 & 1,1316 \\
\cline { 2 - 4 } & $(<0,0001)$ & $(0,0004)$ & $(<0,0001)$ \\
\hline \multirow{2}{*}{ Export } & 0,0595 & $-0,5226$ & 0,0739 \\
\cline { 2 - 4 } & $(0,6118)$ & $(0,3986)$ & $(0,6630)$ \\
\hline
\end{tabular}




\begin{tabular}{|c|c|c|c|}
\hline \multirow{2}{*}{ Explanatory variables } & \multicolumn{3}{|c|}{ Coefficient } \\
\cline { 2 - 4 } & Model 1 & Model 2 & Model 3 \\
\hline \multirow{2}{*}{ Size } & $-0,0014$ & $-0,3003$ & $-0,00581$ \\
\cline { 2 - 4 } & $(0,8991)$ & $(0,0055)^{* * *}$ & $(0,7322)$ \\
\hline \multirow{2}{*}{ Capital turnover } & 0,0273 & 0,0061 & 0,0351 \\
\cline { 2 - 4 } & $(0,0283)^{* *}$ & $(0,9063)$ & $(0,0391)^{* *}$ \\
\hline \multirow{2}{*}{ Revenue cycle } & $-0,0098$ & $-0,2615$ & $-0,0271$ \\
\cline { 2 - 4 } & $(0,8025)$ & $(0,0144)^{* *}$ & $(0,6093)$ \\
\hline \multirow{2}{*}{ Current ratio } & $-0,0220$ & $-0,0265$ & $-0,02281$ \\
\cline { 2 - 4 } & $(0,0355)^{* *}$ & $(0,0353)^{* *}$ & $(0,0382)^{* *}$ \\
\hline \multirow{2}{*}{ Debt ratio } & $-0,00185$ & 0,0900 & 0,0035 \\
\cline { 2 - 4 } & $(0,9742)$ & $(0,6084)$ & $(0,9640)$ \\
\hline \multirow{2}{*}{ Return on assets } & 0,5086 & 0,4196 & 0,4119 \\
\cline { 2 - 4 } & $(0,0035)^{* * *}$ & $(0,0621)^{*}$ & $(0,0286)^{* *}$ \\
\hline
\end{tabular}

Source: Authors

Note: - Model 1: Pooled OLS; Model 2: Fix-effects model; Model 3: Random-effects; (GLS);

- $\quad{ }^{*},{ }^{* *},{ }^{* * *}$ indicate statistical significance at the $90 \%$ and $95 \%$ and $99 \%$ level of confidence.

When analyzing panel data, the most commonly asked question is whether it is better to use a fixed effect model or a random effect model. In order to answer on this question, the panel diagnostics was conducted and it is shown in the Table 5.

Table 5. Panel model diagnostic

\begin{tabular}{|c|c|c|c|}
\hline Diagnostics & Null hypothesis & p value & Decision \\
\hline $\begin{array}{l}\text { Joint significance } \\
\text { of differing group } \\
\text { means: }\end{array}$ & $\begin{array}{l}\text { The pooled } \\
\text { OLS model is } \\
\text { adequate }\end{array}$ & $\begin{array}{c}\mathrm{F}(39,113)=3,2945 \text { with } \\
\text { p-value } 0,000\end{array}$ & $\begin{array}{l}\text { A p-value less than } 5 \%(0.05) \text { counts } \\
\text { against the null hypothesis that the } \\
\text { pooled OLS model is adequate, in } \\
\text { favour of the fixed effects alternative. }\end{array}$ \\
\hline $\begin{array}{l}\text { Breusch-Pagan } \\
\text { test statistic }\end{array}$ & $\begin{array}{l}\text { The pooled } \\
\text { OLS model is } \\
\text { adequate }\end{array}$ & $\begin{array}{c}\mathrm{LM}=13,1729 \\
\text { with } \mathrm{p} \text {-value }=\text { prob(chi- } \\
\text { square }(1)>13,1729)= \\
0,000284031\end{array}$ & $\begin{array}{l}\text { A p-value less than } 5 \%(0.05) \text { counts } \\
\text { against the null hypothesis that the } \\
\text { pooled OLS model is adequate, } \\
\text { in favour of the random effects } \\
\text { alternative. }\end{array}$ \\
\hline $\begin{array}{l}\text { Hausman test } \\
\text { statistic }\end{array}$ & $\begin{array}{l}\text { The random } \\
\text { effects model is } \\
\text { adequate }\end{array}$ & $\begin{array}{c}\mathrm{H}=27,4303 \text { with } \mathrm{p} \text {-value } \\
=\operatorname{prob}(\text { chi-square }(7)> \\
27,4303)=0,000278768\end{array}$ & $\begin{array}{l}\text { A p-value less than } 5 \%(0.05) \text { counts } \\
\text { against the null hypothesis that the } \\
\text { random effects model is adequate, in } \\
\text { favour of the fixed effects alternative. }\end{array}$ \\
\hline
\end{tabular}

Source: Authors 
The results of the panel diagnostics shown in the table above show that the fixed model is the most appropriate (Baltagi, 2005), so in the next section we will comment on the results obtained for this model.

The results of fixed-effects model is shown in Table 6.

Table 6. Fixed-effects model (Dependent variable: Growth)

\begin{tabular}{|l|r|r|r|r|l|}
\hline \multicolumn{1}{|c|}{ Variable } & Coefficient & Std. Error & \multicolumn{1}{c|}{ t-ratio } & \multicolumn{2}{c|}{ p-value } \\
\hline Const & 4.7420 & 1.3066 & 3.6290 & 0.0004 & $* * *$ \\
\hline Export & -0.5226 & 0.6167 & -0.8474 & 0.3986 & \\
\hline Size & -0.3003 & 0.1062 & -2.8280 & 0.0055 & $* * *$ \\
\hline CapTurn & 0.0061 & 0.0518 & 0.1180 & 0.9063 & \\
\hline RevCyc & -0.2615 & 0.1053 & -2.4850 & 0.0144 & $* *$ \\
\hline CurrRatio & -0.0265 & 0.0124 & -2.1310 & 0.0353 & $* *$ \\
\hline Debt & 0.0900 & 0.1752 & 0.5137 & 0.6084 & \\
\hline ROA & 0.4196 & 0.2227 & 1.8840 & 0.0621 & $*$ \\
\hline
\end{tabular}

Source: Authors

Note: - * **, *** indicate statistical significance at the $90 \%$ and $95 \%$ and $99 \%$ level of confidence. As we can see in Table 6, there are four of seven independent variables included in panel analysis that show statistically significance impact on growth as dependent variable:

a) size $(-0.3003)$ shows negative impact on Growth at the level of significance of $1 \%$

b) the average number of days a claim is collected $(-0.2615)$ shows negative impact on Growth at the level of significance of $5 \%$

c) current ratio as liquidity ratio (Acid test) $(-0.0265)$ also shows negative impact on Growth at the level of significance of $5 \%$ and

d) return on assets $(0.4196)$ shows positive impact on Growth at the level of significance of $10 \%$.

According to results it can be conclude that hypothesis was partially accepted. The research results provide that four of seven selected variables have significant impact on growth.

\section{Discussions}

The aim of this paper was to analyze and investigate factors which have significant effects on growth of coffee processing companies in Serbia. According to the results of growth of coffee processing companies in Serbia during the period 2015-2018 it can be conclude that these companies have positive average growth rate of $8 \%$. During the observed period the average rate of growth decreased from 14\% in 2015 to $5 \%$ in 2018 .

The results of panel data analysis indicate that size, revenue cycle, current ratio and return on assets have significant impact on the growth of coffee processing companies. On the other hand, variables such as export, capital turnover and debt ratio do not effect on growth of sales significantly. 
The size has negative significant impact on the growth of companies. According to this it can be conclude that small companies have large growth rate. These results have to be explained by the absolute amount of sale and ratio of sales growth. Smaller companies can achieve larger rate of growth with the smaller absolute amount of sale in one period in difference with larger companies.

Revenue cycle has significant negative effect on the growth of coffee processing companies in Serbia. Results indicate that larger average number of days in which a claim is collected will reduce the rate of sales growth. These finding is according to the results of other authors (Voulgaris, Asteriou, Agiomirgianakis, 2003; Fiala, Hedija, 2015)

Current ratio as the representative of liquidity of companies indicate that there is negative significant relationship between current ratio and growth. These findings indicate that lower liquidity provides higher rate of companies growth. Liquidity of coffee processing companies in Serbia is higher than referent value (average current ratio is higher than 2.00 during the period 2015-2018). The lower liquidity of the fast growing firms is related to their basic fund demand-supply equation, which forces them to economize on use of funds in current asset holdings and to borrow from all possible sources, including banks and trade creditors (Voulgaris, Asteriou, Agiomirgianakis, 2003).

Return on assets has positive significant effect on sales growth. Higher level of return of assets indicates higher rate of sales growth. Coffee processing companies do not have high level of debt, so they rely on their ability to generate profits in order to grow.

\section{Conclusions}

The growth and growth factors of coffee processing companies in the Republic of Serbia was examined during period 2015-2018. An empirical examination is based on financial statements of coffee processing companies, and using of descriptive statistics and panel data analysis. The growth was measured as the changes in sales of companies, while as independent variables are used export, size, capital turnover, revenue cycle, current ratio, debt ratio and return on assets.

The results of growth analysis show that the coffee processing companies in the Republic of Serbia have an average rate of growth at the level of $8 \%$. Beside positive growth rate, coffee processing companies have an average good performances such as return on assets. An average return on assets show that coffee processing companies make net income (profit) of $7 \%$ of total assets. Positive growth and return on assets represent the crucial prerequisites for future development of coffee processing industry in Serbia.

The results of panel data analysis show that size, revenue cycle, current ratio and return on assets have significant impact on growth. Size has negative significant impact at $99 \%$ level of confidence. That mean that small coffee processing companies have better growth rate. At absolute value the growth of these companies is much less than the growth of large companies. Revenue cycle and current ratio have negative significant impact on growth at $95 \%$ level of confidence. Less number of days of claim collection positive influence on growth rate. Negative relationship between current ratio and growth rate can be explained that high current ratio may indicate an inefficient use of cash and other short-term assets 
(see more: Herawati, Fauzia, 2018). Return on assets is positively related to growth of company at $90 \%$ level of confidence. This mean that growth rate of return on assets is related to the increase in sales of coffee processing companies.

An empirical examination provides information about performances of companies from coffee processing industry. The large companies achieve the larger amount of sale, but measured the rate of growth sale it is smaller in difference to the smaller companies. In order to increase the growth rate companies rely on the larger profitability rate, and should make a little decrease of current assets (measured in according to the current debts) and should decrease the average day of a claim collection. These results can be of interest for a different type of users of financial statements such as potential inventors, suppliers, banks, managers, owners etc. in order to make a reliable and adequate business decisions. Also, these results point to the significant factors that have influence on growth of coffee processing companies which can be used as a part of creating a business policy of future growth and development of coffee processing industry.

\section{Conflict of interests}

The authors declare no conflict of interest.

\section{References}

1. Adkins, L. (2014). Using gretl for Principles of Econometrics, 4th Edition Version 1.0411. Oklahoma State University, Oklahoma, USA.

2. Al-Abdulkader, A.M., Al-Namzi, A.A., AlTurki, T.A., Al-Khuraish, M.M., \& AlDakhil, A.I. (2018). Optimizing coffee cultivation and its impact on economic growth and export earnings of the producing countries: The case of Saudi Arabia. Saudi Journal of Biological Sciences. 25(4), 776-782.

3. Aljinović, Z., \& Marasović, B. (2012). Mathematical models in the analysis of the development of the Croatian financial market. Faculty of Economics in Split, Split.

4. Baltagi, B.H. (2005). Econometric analysis of panel data. England: John Wiley \& Sons Ltd.

5. Becchetti, L., \& Trovato, G. (2002). The Determinants of Growth for Small and Medium Sized Firms. The Role of the Availability of External Finance. Small Business Economics, 19(4), 291-306.

6. Callado, A.L.C., \& Soares, K.R. (2014). Analysis of the use of performance indicators in the context of agribusiness. Custos e agronegocio on line, 10(2), 272-284.

7. Daunfeldt, S.O., Elert, N., \& Johansson, D. (2014). The Economic Contribution of High-Growth Firms: Do Policy Implications Depend on the Choice of Growth Indicator? Journal of Industry, Competition and Trade, 14(3), 337-365.

8. Delmar, F. (2006). Measuring Growth: Methodological Considerations and Empirical Results. Entrepreneurship and the Growth of Firms, 1(1), 62-84. 
9. Fiala, R., \& Hedija, V. (2015). The relationship between firm size and firm growth: the case of the Czech Republic. Acta universitatis agriculture et silviculturae mendeliane brunensis, 63(5), 1639-1644.

10. Field, A. (2005). Discovering statistics using SPSS. London: Sage Publications Ltd.

11. Gopinath, R. (2012). Understanding the determinants of firm growth in young REITs. Retrieved from: https://core.ac.uk/reader/48657266 (April 10, 2020)

12. Gulin, D., Grbavac, J., \& Hladika, M. (2016). The quality of corporate reporting as presumption of business entities transparency. Proceedings Journal of Economy and Busines, 22, 154-180.

13. Gupta, P.D., Guha, S., \& Krishnaswami, S.S. (2013). Firm growth and its determinants. Journal of Innovation and Entrepreneurship, 2(15), 1-14.

14. Harabi, N. (2003). Determinants of Firm Growth: An Empirical Analysis from Morocco. Retrieved from: https://www.academia.edu/735195/Determinants_of firm_growth_an_empirical_analysis_from_Morocco (February 12, 2020).

15. Hasanaj, P. (2019). Analysis of Financial Statement. Humanities and Social Science Research, 2(2), 17-27.

16. Herawati, A., \& Fauzia, F.I. (2018). The effect of current ratio, debt to equity ratio and return on assets on dividend payout ratio in sub-sector automotive and component listed in Indonesia Stock Exchange in period 2012-2016. International Conference of Organizational Innovation, 1076-1086.

17. Hermelo, F.D. \& Vassolo, R. (2007). The determinants of firm's growth: an empirical examination. Revista Abante, 10(1), 3-20.

18. International Trade Centre. (2020). Trade statistics for international business development. Retrieved from: https:/www.trademap.org/Index.aspx (April 6, 2020).

19. International Coffee Organization (2020a). Historical Data on the Global Coffee Trade. Retrieved from: http://www.ico.org/new_historical.asp?section=Statistics. (April 6, 2020).

20. International Coffee Organization (2020b). Trade statistics tables. World coffee consumption. Retrieved from: http://www.ico.org/prices/new-consumption-table. pdf. (April 6, 2020).

21. Jakšić, D., Mijić, K., Zekić, S., \& Poljašević, J. (2015). Comparative profitability analysis of milk production companies to milk processing companies in Serbia. Custos e Agronegocio on line, 11(3), 206-226.

22. Machek, O., \& Machek, M. (2014). Factors of Business Growth: A Decomposition of Sales Growth into Multiple Factors. WSEAS Transactions on Business and Economics, 11, 380-385.

23. Milić, D., Mijić, K. \& Jakšić, D. (2018). Opportunistic management behavior in reporting earnings of agricultural companies. Custos e Agronegocio on line. 14(1), 125-142.

24. Ministry of finance of Republic of Serbia. (2017). Explanation regarding the excise tax on coffee from 1 January 2018. Retrieved from: https://www.mfin.gov.rs/ UserFiles/File/misljenja/2017/Objasnjenje\%20akciza\%20kafe.pdf. (April 8, 2020). 
25. Nuševa, D. (2018). Sustainability standards at the global coffee market. The Annals of the Faculty of Economics in Subotica, University of Novi Sad, 54(39), 257-267.

26. Nuševa, D., Mijić, K., \& Jakšić, D. (2017). The Performances of Coffee Processors and Coffee Market in the Republic of Serbia. Economics of Agriculture. 64(1), 307-322.

27. Poljašević, J., \& Mijić, K. (2017). The importance of analytical indicators in assessing the future performance of a company, The Congress of Accountants and Auditors of Montenegro, 243-260.

28. SCORING (2019). Financial statements. Retrieved Decembar $10^{\text {th }} 2019$ from www.scoring.rs

29. Sharma, S., Dhakal, C.K., Ghimire, B., \& Rijal, A. (2016). Economic Significance of Coffee (Coffee Arabica) Production in Parbat District of Nepal. International Journal of Agricultural Management and Development, 6(2),123-130.

30. Shepherd, D., \& Wiklund, J. (2009). Are we comparing apples with apples or apples with oranges? Appropriateness of knowledge accumulation across growth studies. Entrepreneurship Theory and Practice, 33(1), 105-123.

31. Silva, O.M., \& Leite, C.A.M. (2013). Income Content of the World Coffee Exports. AD-minister Medellin-Columbia, 22, 69-82.

32. Statista (2020). Coffee Serbia. Retrieved from: https://www.statista.com/ outlook/30010000/150/coffee/serbia. (April 7, 2020).

33. Subačienè, R., Alver, L., Brūna, I., Hladika, M., Mokošová, D., \& Molín, J. (2018). Evaluation of accounting regulation evolution in selected countries, Entrepreneurship and Sustainability, 6(1), 139-175.

34. Voulgaris, F., Asteriou, D., \& Agiomirgianakis, G. (2003). The determinants of small firm growth in the Greek manufacturing sector. Journal of Economic Integration, 18(4), 817-835.

35. Walsh, C. (2003). Key Management Ratios. London, United Kingdom: Prentice Hall. 